\title{
The effect of the cyberloafing behaviors of tourism business employees on business motivations and organizational identification
}

\section{O efeito dos comportamentos de cyberloafing dos empregados de empresas turísticas nas motivações e na identificação organizacional}

\author{
Kerem Kaptangil \\ Sinop University, Turkey, kerem_kaptangil@hotmail.com \\ Kübra Asan \\ Sinop University, Turkey, kubra.asan@hotmail.com \\ Aysun Gargaci Kinay \\ Sinop University, Turkey, aysungargaci34@hotmail.com
}

Received: 10.06.2020; Revisions required: 14.07.2020; Accepted: 02.11.2020

\begin{abstract}
With the development of communication technologies, cyberloafing, which means the use of tools such as telephone, tablet, or Internet for business or individual purposes, has become a subject of debate. From this point of view, the cyberloafing behavior of employees in tourism enterprises was examined. It was aimed to investigate the effects of cyberloafing on business motivations and organizational identification in tourism businesses. For this purpose, field research was conducted on hotel management employees in the cities of Sinop and Samsun in Turkey. The data collected through questionnaires were analyzed by factor analysis and Partial Least Squares Structural Modeling (PLS). Findings indicate that cyberloafing has partially and relatively low impact on job motivation and organizational identification. The results of the study contribute to the literature of organizational behavior in the context of cyberloafing, and offer suggestions for hotel managers.
\end{abstract}

Keywords: Cyberloafing, motivation, organizational identification, tourism enterprises, employee behavior.

\section{Resumo}

Com o desenvolvimento das tecnologias de comunicação, o cyberloafing, que significa o uso de ferramentas como telefone, tablet ou internet para fins comerciais ou individuais, tornou-se objeto de debate. Desse ponto de vista, foi examinado o comportamento de cyberloafing de funcionários em empresas turísticas. O objetivo foi investigar os efeitos do cyberloafing nas motivações empresariais e na identificação organizacional. Para esse efeito, foi realizada investigação de campo com funcionários de gestão hoteleira nas cidades de Sinop e Samsun, na Turquia. Os dados recolhidos por meio de questionários foram analisados através de análise fatorial e Partial Least Squares Structural Modeling (PLS). Os resultados indicam que o cyberloafing tem impacto parcial e relativamente baixo na motivação do trabalho e na identificação organizacional. Os resultados do estudo contribuem para a literatura sobre comportamento organizacional no contexto do cyberloafing e oferecem sugestões para os gerentes de hotéis.

Palavras-chave: Cyberloafing, motivação, identificação organizacional, empreendimentos turísticos, comportamento dos funcionários.

\section{Introduction}

Today, the importance of internet use is increasing both in social life and business life. This increase in the level of importance stems from people's desire for decision-making by evaluating the activities they want to perform in their daily lives and business lives faster, more efficiently and at the highest possible level. The internet environment, which is the most suitable area to meet these needs, has been the subject of many researches, especially on its effects on the working life of employees through different variables. Within the framework of these examinations, it was determined that 63 percent of smartphone users in the world could not stop using their phones every half an hour and 22 percent every 5 minutes. In addition, according to the information collected by IAB's Mobile Consumer Experiences Survey conducted in 18 countries, it was concluded that many people around the world access the Internet at least once a day via the web or a mobile application (İşgüzar \& Ayden, 2017). As a result of the widespread use of the Internet that varies in content, the areas and the degree of influence of this time allocated to the Internet on employees have been the subject of research (Urgin \& Pearson, 2007; Lim \& Teo, 2005; Friedman, 2000; İnce \& Gül, 2011; Anandarajan \& Simmers, 2005).
The human model that people come across in the modern management approach is accepted as an element that must be evaluated outside of working life. For this reason, the fact that the practices related to working life are only limited to the work environment, the idea that employees cannot make an impact on their work environment due to their lives outside of work and their effects on them is just an assumption. However, many studies on the Internet and working life (Lim, 2002; Anandarajan, 2004; Mahatanankoon et al. 2004; Li \& Chung, 2006; Mastrangelo et al., 2006; Blanchard \& Henle, 2008; Doorn, 2011; Ramayah, 2010) revealed that the time employees spend on the Internet affects many aspects of their working lives and to different degrees.

There are a few elements on which researchers offer different opinions regarding cyberloafing, which is the subject of researches with many different names. The first of these is the classification of cyberloafing actions, that is, the use of nonbusiness Internet for different purposes and the actions they contain may differ. The differentiation of these classifications and actions, on the other hand, has been a new topic of discussion regarding the perception of cyberloafing behaviors as threats or 
opportunities in the work environment. At this point, cyberloafing will decrease productivity and efficiency due to the inefficient use of time and resources in the workplace and cause economic losses (Mills et al., 2001; Lim, 2002; Lim \& Teo, 2005; Beugre \& Kim, 2006; Ugrin, Pearson \& Odom, 2007). Views such as that it will cause a violation of information security and privacy against the organization (Eivazi,2011), that organizations should be confronted with legal cases and legal obligations (Mills et al., 2001; Eivazi, 2011; Kaplan \& Ögüut, 2012) and that it will cause image loss along with financial losses to the organization due to copyright problems, wasted talent/computers/human resources, illegal events (mp3, video download, IT crime) have been defended (Scheuermann \& Langford, 1997). On the other hand, there are researchers defending that, as long as the balance is achieved, it affects emotions positively, creates a culture of freedom and routine practices, takes away worries and stress from work, and stimulates the mind, thus increasing efficiency by motivation (Mahatanankoon \& Igbaria, 2004; Beugre \& Kim, 2006; Lim \& Chen, 2012) and increases organizational learning by providing opportunities (Anandarajan \& Simmers, 2005). Thanks to the learning environment it offers, creativity, flexibility, worklife balance, emotional commitment, employee satisfaction, positive perception of the workplace, and job satisfaction rates are higher (Block, 2001; Stanton, 2002; Anandarajan et al., 2004; Blanchard \& Henle, 2008; Vitak et al., 2011).

Regarding cyberloafing, the position and belonging of the employee in the organization should also be discussed. There is no research in the literature on the effects of cyberloafing on the business motivation of the employee and the resulting organizational identification that the research is trying to reveal. The organizational justice element of cyberloafing has been discussed with themes such as (Lim \& Teo, 2005; Syaebani \& Sobri, 2011) organizational trust (Marcus \& Schuler, 2004), personality (Jia, H., Jia, R., \& Karau, S., 2013), stress (Kutanis et al., 2014), psychological contract (Iyigun, 2014), organizational citizenship (Anandrajan \& Simmer, 2005; Urgin et al., 2007), job performance (Fındıklı, 2016), time management (Genç \& Aydoğan, 2016), and internet addiction (Öztürk \& Dündar, 2015). Within the framework of positive and negative opinions, the effects of cyberloafing on organizational identification through business motivation and organizational thinking are considered to be included in the literature, and it is thought that the information to be obtained in this field will bring different perspectives to management in enterprises where internet use is increasing day by day.

\section{Cyberloafing}

The concept of cyberloafing emerged with the use of cyber sciences and especially the Internet in business life. The concept of "Loafing", which is a part of this concept, means "avoiding doing a job" (Turkish Language Association, 2011). In the international literature, it was first used by Lim (2002) based on the classification made by Robinson and Bennett (1995). Performing the loafing actions through the use of computer components and the Internet has brought up the concept of
"Cyberloafing/Idleness". In addition, this phenomenon is expressed with concepts such as Cyberloafing (Candan \& Ince, 2016), Cyber Idleness (Serttaş \& Şimşek, 2017) and Cyber Laziness in the national literature (Genç \& Aydoğan, 2016). Looking at the definitions about cyberloafing, the first definition was made by Kamins in 1995 as the misuse of information and communication technologies for non-work-related activities in workplaces (Jandaghi et al., 2015). Ugrin, Pearson and Odom (2007) defined cyberloafing as an inefficient time on the Internet. According to Johnson and Indvik (2003), sites with sexual content, news sites, shopping, vacation planning, gambling, chatting, job search or any non-business-related internet use are cyberloafing. According to these definitions, common points of cyberloafing are its conduct during working hours, being voluntary actions of employees, not being related to workplaces or being done by employees for their own personal purposes. When these common points are analyzed, some cyberloafing behaviors include reading news, shopping, exchanges and investment transactions on websites, entering social media and chat sites, searching for new jobs, sending/receiving personal e-mails, entering betting sites, and listening to music (Lim \& Teo, 2005; Blanchard \& Henle, 2008). As a result, many researchers scaled the stated common points by making different groupings and included them in their researches.

In the classification made by Lim (2002), cyberloafing behaviors are divided into two groups as e-mail activities and surfing activities. Anandarajan et al. (2004) stated that employees are faced with four types of cyberloafing behavior. These are recreational, harmful, personal learning and vague cyberloafing. Mastrangelo et al. (2006) divided cyberloafing behaviors into anti-productivity and harmful cyberloafing behaviors.

These harmful behaviors create increasing costs for businesses. Therefore, cyberloafing should be prevented by managers regardless of their type. There are two different approaches in the literature about the losses and benefits of cyberloafing for the organization. While some researchers say that cyberloafing is an extremely harmful phenomenon that causes loss of productivity and exposes businesses to legal sanctions (Yıldız \& Yıldız, 2015; Örücu \& Yıldız, 2014; Eivazi, 2011; Mills et al., 2001), a number of researchers (Örucu \& Yıldız, 2014; Anandarajan et al., 2004) emphasize the personal development opportunities, increased productivity and unique learning opportunities achieved through cyberloafing. These behaviors must be managed, taken under control, followed, taken precautions and disciplined (Block, 2001). On the other hand Carlson and Zivnuska (2016) point out that the use of social media should be encouraged by supporting that both task-oriented and relationship-oriented activities can be carried out simultaneously. It is also claimed that, thanks to insignificant cyberloafing behaviors, employees can be evaluated positively because they get away from their daily routine work and relieve work stress (Ugrin \& Pearson, 2013). These activities increase creativity, flexibility, collaboration and create a learning environment, making an indirect impact on productivity in general, according to Blanchard and Henle (2008). Thus, the 
formation of a culture that supports freedom rather than a prohibitive understanding encourages employees to more productive mental and social efforts. Research shows that internet use will contribute to the workplace, such as access to more information by employees, increasing the efficiency of the organization, reducing work stress, increasing job satisfaction and creativity (Vitak et al., 2011). However, the use of Internet for personal purposes in the workplace may cause people to not use their time efficiently (Lim \& Teo, 2005) and sometimes cause businesses to experience some legal problems (Kaplan \& Öğüt, 2012).

However, in a study conducted by Stanton (2002), it was observed that the job attitudes of employees who use the Internet frequently interact very well in terms of organizational factors. In the research conducted by ince and Gül (2011), it was determined that insignificant cyberloafing behavior by employees contributed positively to their job performance and decreased their intention to quit.

There is no study in the literature to reveal the relationship between cyberloafing and business motivation and organizational identification. The research aimed to measure the effect of cyberloafing behaviors on the definition of organizational identification and business motivation within the framework of the theoretical information given within the scope of these three variables.

\section{Business Motivation}

Technological developments, globalization, and increasing competition conditions that emerge in the working life and across the sectors in which they operate, put pressure on businesses and indirectly on employees. For this reason, businesses have to constantly improve their products, services, processes and indirect systems. For these processes that need to be developed, employees need to be motivated to adapt to renewed systems and to set clear goals. The operation of a well-motivated process towards set goals can only be achieved with well-motivated personnel. Achieving success with staff who are not motivated for organizational purposes in terms of desired gains at the organizational level will not be at the specified levels (Öztürk \& Dündar, 2003). Studies on motivation have addressed motivation from many different perspectives and made different definitions because it can be perceived differently by individuals. According to Ruthankoon and Ogunlana (2003), motivation is to decide on the path to be taken to mobilize people. According to Bratton (2007), motivation is the whole of consciously made decisions that determine continuity and direction of behaviors towards determined goals. According to another definition, motivation is the cause for individuals to exhibit behaviors at specified levels, the encouragement for these behaviors and the activation of the internal motivation for people to desire performing the tasks assigned to them (Güney, 2011).

According to the results derived from these definitions, it is very important to have a goal to be motivated. The concept of motivation to be fulfilled in a healthy way for organizations and at the same time employees being successful in common goals with their organizations is only possible with a complete fulfillment of motivation components. These components are put forward as four main elements. Firstly, motivation should be adopted as a personal phenomenon and the personal differentiation of the perception of motivation should be emphasized. Secondly, motivation is the result of an element of intent that can vary depending on individuals. Motivation and its intentions are under the control of employees and diversification of required behaviors is under the influence of the factor of motivation. Thirdly, motivation is a multi-faceted understanding. The factors that make up motivation can change over time and the degree of making employees more active may differ. Fourth and the last factor is that motivation is not a behavior pattern or a performance concept. The concept of motivation emerges as the sum of the forces that can affect a person internally and externally.

Research related to motivation in the tourism sector in the literature (Çetinkaya, 2011; Aslan et al., 2014; Yıldırım \& Arslan, 2015) tried to explain with which elements employees are motivated internally and externally. Business motivation was examined with many different variables in the researches and as a result, efforts were made to increase business motivation in the work environment. This research aims to reveal the relationship between organizational identification and motivation, but to observe the degree to which these two variables can explain each other, the cyberloafing variable has been added to the research.

\section{Organizational Identification}

Today, external environmental factors and change of conditions have brought importance to the relationship of belonging between the organization and the individual. Beyond classic expectations such as loving the institution, loyalty, belonging and not intending to leave, the organization wants individuals to integrate and identify themselves with the organization. It is extremely important for individuals to have a high sense of belonging, to be proud of the organization which they work in, and to ensure that the organization achieves its goals and is successful. The reason organizational behavior and management sciences increase their interest in this concept is that it is a key psychological factor between the employee and the organization. It is also important in reflecting the attitudes, relationships, decisions, and strategic perceptions of members within the organization (Edwards, 2005).

In the business life, individuals want to satisfy their sense of belonging and need for the organizations they are affiliated with, while organizations want to increase and strengthen this sense of identification. The reason for this is the organization's belief that individuals will work more effectively and perform better when they are identified with the organization. When the concept of organizational identification is examined, it cannot be said that there is a common definition in the related literature. The reason is that many researchers examine the concept from different perspectives. Generally, organizational identification has been 
examined in the field of organizational behavior and organizational communication, while identification in the organizational behavior literature is addressed in terms of individual or micro organization; identification created through communication-based strategies spread by management in the organizational communication literature, in other words, focuses on the macro-organizational perspective (Chreim, 2002).

The first study directly pointing to identification was done by Edward Tolman (1943). In this study, identification is considered as an individual's feeling of attachment to a group. A subsequent study was published by Foote in 1957. Foote (1957) described identification as a process in which individuals are effectively connected with their friends in a group, similar to Tolman's definition. Hall et al. (1972) define organizational identification as the integration and harmonization between the goals of the organization and the goals of the individual. Cheney (1983) stated that organizational identification is an active process where individuals combine themselves with events in their social groups.

Many definitions and researches made it possible to evaluate organizational identification from different perspectives and to measure it with many models over the years. A limited number of articles published in the 1970s shed light on the concept of organizational identification with different models (Schneider, Hall \& Nygren, 1971; Hall \& Schneider, 1972; Rotondi, 1976). A few years later, Ashforth and Mael (1989) conducted a study to understand the theory of social identity and organizational identification. Later, Mael and Ashforth (1992) developed an organizational identification scale that is used in this research and will be widely used. Many studies that follow this scale, such as Reade (2001), Riketta (2005), Harris and Cameron (2005), Mignonac, Herrbach, and Guerrero (2006) and Morkness (2014) made several contributions to the literature on organizational identification.

Organizational identification has long been seen as a critical value for organizations. It redefines emotions within the organization and strengthens feelings such as loyalty and commitment. New members get used to the organization in this way (Mael \& Ashford, 1989). Here, acceptance into the organization and the ability continuously to create a culture, as well as motivated employees are important reference sources for the evaluations of the work discipline they apply within the organization.

\section{The Relationship between Cyberloafing, Motivation and Organizational Identification}

In response to technological and economic developments, the behavioral attitudes of customers towards these developments have led businesses to implement new methods of efficiency by following different strategies in terms of both products, services, and human resources. Among the applications made for employees within the framework of these practices, only the flexible applications that see employees as human beings and accept them with many different aspects have achieved accomplishments. Accepting that employees have a social life outside of their work life and environment, and their psychological changes and behaviors are influenced by many factors other than work, practices aim to provide employee satisfaction by creating work environments where the employee will work more comfortably and adopt to more and more each day.

The activities carried out over the Internet in the work environment, which are expressed as cyberloafing and are often not related to the job, but where the employee performs different social behaviors, are also examined as research subjects since they are common behaviors in the work environment. When this review is evaluated in terms of employees and businesses, it is necessary to examine it from two different perspectives. The first is the harmonization in work and business life at the point of employee satisfaction and evaluation thereof from a holistic perspective. The aim here is to strengthen the employee's bond to the enterprise and to make them keep working. The second is to control the negative impact of nonbusiness internet habits on productivity in terms of time and performance in the work environment. Practices in these two processes are all about the organizational culture and motivation strategies of businesses.

If the human workforce that needs to be motivated provides the motivation tool with its cyberloafing behavior, businesses will need to determine the limitations in their control mechanisms. At this point, there is a need to measure the impact of cyberloafing behaviors on the motivation of employees and to reveal the effect of the variables that are the subject of the research. The reason for this may be due to the assumption that employees engaged in cyberloafing behavior cannot see motivation sources differently in business and social life. Employees are always able to provide the motivation tool in relation to the job, not from the work environment, but from many different social environments. Therefore, the effect of cyberloafing behaviors on motivation should be revealed. The degree to which this interaction can be achieved is closely related to the point of view of businesses towards cyberloafing behavior. Some previous studies (Mills et al., 2001; Lim, 2002; Lim \& Teo, 2005; Beugre \& Kim, 2006; Ugrin, Pearson \& Odom, 2007; Eivazi, 2011; Kaplan \& Öğüt, 2012; Scheuermann \& Langford, 1997) have argued that factors such as efficiency, organizational privacy, legal obligations, economic losses, wasted time, and image loss were negatively affected. However, there are also studies in the literature claiming that these behaviors increase organizational citizenship, creativity, satisfaction, job satisfaction, and learning opportunities in the business (Mahatanankoon \& Igbaria, 2004; Beugre \& Kim, 2006; Ince \& Gül, 2011; Lim \& Chen, 2012; Anandarajan \& Simmers, 2005; Block, 2001; Stanton, 2002; Anandarajan et al., 2004; Blanchard \& Henle, 2008; Vitak et al., 2011). Within the framework of these different studies, the fact that there is no study in the literature regarding the motivational and organizational identification variables of cyberloafing and the effects of cyberloafing behaviors on these two variables proves that our study is important in terms of its contribution to the 
literature. For this reason, the following hypotheses will be evaluated in terms of planning and conclusion of the research:

$\mathbf{H}_{\mathbf{1}}$ : Cyberloafing has a significant and positive effect on intrinsic motivation.

$\mathbf{H}_{\mathbf{2}}$ : Cyberloafing has a significant and positive effect on extrinsic motivation.

$\mathbf{H}_{3}$ : Cyberloafing has a positive and significant effect on organizational identification.

\section{Research Methodology}

In line with the purpose of the research, a survey was conducted using quantitative research methods. The theoretical universe of the survey is comprised of the hospitality employees in Sinop and Samsun in Turkey. Simple random sampling method, which is one of the probabilistic sampling techniques, was applied and data was collected with the survey technique. 4- and 5-star hotels in Samsun and Sinop constituted the universe of the research. There are six 5-star and four 4-star hotels in the cities of Sinop and Samsun (Samsun Provincial Culture and Tourism Directorate, 2020). The research was carried out at a time when the number of employees was limited due to the winter season. For this reason, there were 130 employees in total and 100 surveys were included in the research. According to an error margin of 0.05 (1.95), a sample of 130 people can represent 97 samples (Marlies \& Tripepi, 2010).

In the questionnaire used, questions related to job motivations, identification with the institution they worked with, and cyberloafing situations, as well as questions regarding the demographic characteristics of the participants were included. The questionnaire was created in parallel with the literature review. Dundar, Özutku and Taşpınar's (2007) 24-item business motivation scale was used to examine the motivations of the employees; Tan and Demir's (2018) 27-item cyberloafing scale was used to examine cyberloafing situations, which was adapted from Blanchard and Henle (2008); lastly, Mael and Ashforth's (1996) 6-item organizational identification scale was used to examine organizational identification situations. All construct items were measured using five-point Likert-type scales anchored by "strongly disagree" (1) and "strongly agree" (5).

The implementation of the research was carried out between October 28th 2019 - December $6^{\text {th }}, 2019$, including preapplication. The survey data were obtained from the employees of 8 hotel businesses with tourism business certificates in Sinop and Samsun. As a result of the survey, a total of 100 available questionnaires were obtained.

The collected data were subjected to a number of preparatory processes prior to multivariate analysis. Firstly, loss value analysis was performed. Low loss value was observed in the data set. The average value of the relevant series was assigned for the current loss values (Hawthorne \& Elliot, 2005). Secondly, outlier observation was done in the data set. Outliers may arise due to errors in data entry or the unit may not be a member of the universe from which the sample is taken and may disrupt the data set (Tabachnick \& Fidell, 2011). Based on this, standardized $z$ values were used in outlier observation. Values of 4.0 standard deviations from the average were determined as outliers (Hair, Black, Babin, \& Anderson, 2010). Surveys that were outliers were excluded from the analysis and the analysis continued with the remaining 97 surveys. Finally, normal distribution analysis was performed considering the skewness and kurtosis values on the data set. In the literature, kurtosis and skewness values in the range of \pm 2 indicate that the data show normal distribution (Cameron, 2004: 544). In some items in the data set, it was determined that this value range was exceeded, and square root transformation was applied (Ghiselli, Campbell \& Zedeck, 1981). After the root transformation, it was concluded that the data showed normal distribution. Finally, descriptive statistics analysis, Principal Component Analysis (PCA), confirmatory factor analysis (CFA), and partial least squares structural modeling (PLS) were used to analyze the data in the study.

PLS-SEM is frequently used in tourism studies (Zhang, Yang, Zheng \& Zhang, 2016; do Valle \& Assaker, 2015; Daskin, 2013). There are several advantages provided by this method, first of which is its ability to model latent constructs as either formative or reflective (Chin, 1998). Also, PLS makes minimal demands in terms of sample size to validate a model, compared to alternative structural equation modeling techniques. PLS can be used to examine structural models when the multivariate normality of the data cannot be supported (Chin \& Newsted, 1999; Chin, 1998). In PLS application, the two-step data analysis approach proposed in Chin (2010) study was followed. Firstly, the reliability and validity of the measurement model were tested. Then, the structural model, which examines the relationships between the structures, was tested. Type of the structural model is reflectiveformative, performing a double explanation comprised of reflective and formative measurements (Afthanorhan, 2014).

SPSS 21 and SmartPLS 2.0 analysis software were used in data analysis. In SPSS, Principal Component Analysis (PCA) was performed. SmartPLS is used for the confirmatory factor analysis (CFA) and the testing of the structural model.

\section{Results}

\subsection{Descriptive Statistics}

In the analysis of the data obtained in the study, the demographic information of the participants was first examined at the descriptive level and is summarized in Table 1 . It is seen that the ages of the participants were mostly between $18-37$ years. The ratio of male participants was relatively higher compared to women. Similarly, when the marital status of the participants is analyzed, it was seen that the ratio of single people was relatively high. As a remarkable finding, it was noted that the education levels of the participants were relatively high. Accordingly, $60 \%$ of the participants were undergraduate graduates. On the other hand, it is understood that the working times of the participants in the existing workplaces were mostly in the range of 4-6 years. 
Table 1 - Characteristics of the Participants

\begin{tabular}{|c|c|c|c|c|}
\hline \multicolumn{2}{|c|}{ Variable } & \multirow{2}{*}{$\begin{array}{c}\mathbf{n} \\
37\end{array}$} & \multirow{2}{*}{$\begin{array}{c}\% \\
39.8 \\
\end{array}$} & \multirow{2}{*}{$\begin{array}{c}\text { Cumulative \% } \\
40.7 \\
\end{array}$} \\
\hline \multirow{7}{*}{ Age } & $18-27$ & & & \\
\hline & $28-37$ & 33 & 35.5 & 36.3 \\
\hline & $38-47$ & 18 & 19.4 & 19.8 \\
\hline & $48-57$ & 3 & 3.2 & 3.3 \\
\hline & Total & 91 & 97.8 & 100.0 \\
\hline & Missing & 2 & 2.2 & \\
\hline & Total & 93 & 100.0 & \\
\hline \multirow{5}{*}{ Gender } & Female & 40 & 43.0 & 44.0 \\
\hline & Male & 51 & 54.8 & 56.0 \\
\hline & Total & 91 & 97.8 & 100.0 \\
\hline & Missing & 2 & 2.2 & \\
\hline & Total & 93 & 100.0 & \\
\hline \multirow{5}{*}{ Marital Status } & Married & 42 & 45.2 & 46.2 \\
\hline & Single & 49 & 52.7 & 53.8 \\
\hline & Total & 91 & 97.8 & 100.0 \\
\hline & Missing & 2 & 2.2 & \\
\hline & Total & 93 & 100.0 & \\
\hline \multirow[t]{6}{*}{ Education Status } & Primary school & 4 & 4.3 & 4.3 \\
\hline & Secondary school & 7 & 7.5 & 11.8 \\
\hline & High school & 22 & 23.7 & 35.5 \\
\hline & Graduate & 56 & 60.2 & 95.7 \\
\hline & Higher education & 4 & 4.3 & 100.0 \\
\hline & Total & 93 & 100.0 & \\
\hline \multirow{8}{*}{ Working duration } & Less than 1 year & 14 & 15.1 & 15.2 \\
\hline & 1-3 year & 17 & 18.3 & 18.5 \\
\hline & 4-6 year & 41 & 44.1 & 44.6 \\
\hline & 7-9 year & 16 & 17.2 & 17.4 \\
\hline & Over 10 years & 4 & 4.3 & 4.3 \\
\hline & Total & 92 & 98.9 & 100.0 \\
\hline & Missing & 1 & 1.1 & \\
\hline & Total & 93 & 100.0 & \\
\hline
\end{tabular}

\subsection{Measurement Model}

First, the principal components analysis (with varimax rotation and an eigenvalue of 1.00 or more for the identification of potential factors) was used to obtain latent variables. Kaiser-Meyer-Olkin (KMO) test was applied, which showed that the sufficient sample size was reached. The KMO test value of the business motivation scale was 0.863 ; the KMO test value for the cyberloafing scale was 0.761; the KMO test value for the organizational identification scale was 0.810 , and it was concluded that the sample had a good volume for factor analysis (Pallant, 2013). Bartlett Test results were found to be significant for each structure $(p=0.000)$ to determine that there was a linear correlation between the variables. Items whose factor load values in more than one dimension were closer than 0.10 were excluded from the analysis because they had comorbid factor loads (Item et al., 2010). As a criterion of safety, items below 30 total correlation values were excluded on the grounds that they did not serve the overall scale (Tinsley \& Brown, 2000).

After the PCA was implemented using SPSS, the cyberloafing factor structure consisting of 18 items with four factors was reached in the cyberloafing variable. Factors are named as "Social purpose", "Learning purpose", "Regular use" and "Irregular use" in accordance with their content. After removing items with comorbid factor loads on the business motivation scale, a 2-factor structure, named "Intrinsic motivation" and "Extrinsic motivation", was obtained. Organizational identification structure maintained its status. Then, the structures followed the CFA. CFA was implemented using SmartPLS. First, Composite reliability (CR) and Cronbach's alpha $(\alpha)$ values of the measurement model were examined. As seen in Table 2, Cronbach's alpha is above the recommended value of 0.6 (Nunnally, 1967). The composite reliability values of all constructs ranged from 0.82 to 0.89 , so all were above (better than) the recommended benchmark of 0.70 (Fornell and Larcker, 1981). Table 2 also includes the factor loads of each item. Individual item reliability can be assessed by examining the loadings (Hulland, 1999). Accordingly, factor loadings were greater than 0.50 , which suggests satisfactory convergent validity and item reliability (Barclay, Thompson \& Higgins, 1995; Hulland, 1999; Chin, 1998). In addition, the average variance extracted (AVE) values were at an acceptable level, above 0.50 (Fornell \& Larcker, 1981). The Fornell-Larcker criterion was examined for discriminant validity of the data. As seen in Table 3, the square root of AVE for each construct is greater than the levels of correlations involving the construct (Fornell \& Larcker, 1981). Henseler, Ringle and Sarstedt (2015) have suggested an alternative approach, based on the multitrait-multimethod matrix, to assess discriminant validity in the form of heterotrait-monotrait (HTMT) ratio of correlations. All the values passed an HTMT of 0.90 (Gold, Malhotra \& Segars, 2001) as shown in table 4, indicating that discriminant validity has been ascertained. It is also understood that there is no multicollinearity problem 
in the data since there is no correlation greater than 0.90 between the structures (Tabachnick \& Fidell,1996). The examinations show that the measurement model has sufficient validity and reliability. Based on these findings, the structural model analysis, which is the second stage of the analysis, has been started.

Table 2 - Scale items, reliabilities, and confirmatory factor analysis results

\begin{tabular}{|c|c|c|c|c|}
\hline Scale items & $\begin{array}{c}\text { Factor } \\
\text { Loadings }\end{array}$ & $\alpha$ & CR & AVE \\
\hline Social purpose & & 0.819 & 0.866 & 0.521 \\
\hline I listen to music or watch videos via the Internet. & 0.820 & & & \\
\hline I visit websites about entertainment. & 0.747 & & & \\
\hline I download files (such as music, software, video...) & 0.789 & & & \\
\hline I chat with my friends via the Internet. & 0.699 & & & \\
\hline I'm browsing the Internet for fun. & 0.641 & & & \\
\hline I browse the Internet aimlessly. & 0.610 & & & \\
\hline Learning purpose & & 0.784 & 0.848 & 0.527 \\
\hline I do research for hobby purposes via the Internet. & 0.743 & & & \\
\hline I visit virtual communities / forums. & 0.726 & & & \\
\hline I follow academic and scientific publications and news. & 0.702 & & & \\
\hline I do research on the Internet about topics I am interested in. & 0.763 & & & \\
\hline I read the blog pages. & 0.695 & & & \\
\hline Irregular use & & 0.721 & 0.822 & 0.539 \\
\hline I visit real estate sites. & 0.818 & & & \\
\hline I visit websites related to financial investment & 0.750 & & & \\
\hline I shop online for personal products. & 0.726 & & & \\
\hline I visit sports websites. & 0.629 & & & \\
\hline Regular use & & 0.673 & 0.820 & 0.605 \\
\hline $\begin{array}{l}\text { I perform banking transactions over the Internet (such as EFT, Money } \\
\text { Order transactions). }\end{array}$ & 0.724 & & & \\
\hline I visit general news websites. & 0.722 & & & \\
\hline I check my emails. & 0.878 & & & \\
\hline Intrinsic motivation & & 0.856 & 0.888 & 0.503 \\
\hline $\begin{array}{l}\text { The attitudes and behaviors of my colleagues that honor } \\
\text { and motivate me. }\end{array}$ & 0.791 & & & \\
\hline It motivates me to believe that the work I do is worth doing. & 0.821 & & & \\
\hline Having the full authority for my job motivates me. & 0.814 & & & \\
\hline $\begin{array}{l}\text { Seeing myself as an important employee of the business } \\
\text { motivates me. }\end{array}$ & 0.655 & & & \\
\hline $\begin{array}{l}\text { The suitability of physical conditions in my work } \\
\text { environment motivates me. }\end{array}$ & 0.620 & & & \\
\hline $\begin{array}{l}\text { Providing facilities such as food, tea and coffee free of } \\
\text { charge motivates me. }\end{array}$ & 0.757 & & & \\
\hline $\begin{array}{l}\text { It helps me to motivate my manager to resolve my disputes } \\
\text { with colleagues or customers. }\end{array}$ & 0.571 & & & \\
\hline My reward for my success motivates me. & 0.593 & & & \\
\hline Extrinsic motivation & & 0.822 & 0.871 & 0.532 \\
\hline Honorable attitudes and behaviors of the managers motivate me. & 0.729 & & & \\
\hline Giving permission when I need to use permits motivates me. & 0.742 & & & \\
\hline Adequate tools and equipment in the workplace motivates me. & 0.772 & & & \\
\hline Having good relations with employees motivates me. & 0.797 & & & \\
\hline Having good relations with my manager motivates me. & 0.737 & & & \\
\hline Having the opportunity to be promoted motivates me. & 0.579 & & & \\
\hline Organization identification & & 0.851 & 0.891 & 0.581 \\
\hline When someone criticizes the business I work for, I feel like I am insulted. & 0.579 & & & \\
\hline What other people think about the business I work for is important to me. & 0.780 & & & \\
\hline When I talk about the business I work for, I usually use the expression "We" & 0.742 & & & \\
\hline I feel the success of the business I work for is my own success & 0.840 & & & \\
\hline $\begin{array}{l}\text { I feel like I am complimented when someone speaks very praiseworthy for the business I } \\
\text { work for. }\end{array}$ & 0.872 & & & \\
\hline I feel bad when there is a criticism of the business I work in the media. & 0.723 & & & \\
\hline
\end{tabular}

All items are measured on five-point Likert scales ranging from $1=$ strongly disagree to $5=$ strongly agree. All loadings are significant at the 0.01 . 
Table 3 - AVE, Correlations, means, standart deviations of model constructs

\begin{tabular}{|l|c|c|c|c|c|c|c|c|c|}
\hline Constructs & Mean & $\begin{array}{c}\text { Standart } \\
\text { Deviation }\end{array}$ & $\mathbf{1}$ & $\mathbf{2}$ & $\mathbf{3}$ & $\mathbf{4}$ & $\mathbf{5}$ & $\mathbf{6}$ & $\mathbf{7}$ \\
\hline 1. Social purpose & 4.03 & 1.037 & $\mathbf{0 . 7 2 2}$ & & & & & & \\
\hline 2. Learning purpose & 3.44 & 1.162 & 0.395 & $\mathbf{0 . 7 2 6}$ & & & & & \\
\hline 3. Irregular use & 3.44 & 1.300 & 0.270 & 0.397 & $\mathbf{0 . 7 3 4}$ & & & & \\
\hline 4. Regular use & 4.00 & 1.101 & 0.339 & 0.479 & 0.462 & $\mathbf{0 . 7 7 8}$ & & & \\
\hline 5. Intrinsic motivation & 4.65 & 0.550 & 0.485 & 0.229 & 0.309 & 0.453 & $\mathbf{0 . 7 0 9}$ & & \\
\hline 6. Extrinsic motivation & 4.40 & 0.747 & 0.468 & 0.199 & 0.227 & 0.358 & 0.729 & $\mathbf{0 . 7 3 3}$ & \\
\hline 7. Organization identification & 4.03 & 0.906 & -0.103 & 0.175 & -0.109 & 0.106 & 0.128 & 0.178 & $\mathbf{0 . 7 6 0}$ \\
\hline
\end{tabular}

Note: The diagonal elements (in bold) represent the square roots of the AVE of each construct. The off-diagonal elements represent the correlations among constructs.

Table 4 - Discriminant Validity (HTMT Ratio)

\begin{tabular}{|l|c|c|c|c|c|c|}
\hline Constructs & $\mathbf{1}$ & $\mathbf{2}$ & $\mathbf{3}$ & $\mathbf{4}$ & $\mathbf{5}$ & $\mathbf{6}$ \\
\hline 1. Social purpose & & & & & & \\
\hline 2. Learning purpose & 0.509 & & & & & \\
\hline 3. Irregular use & 0.422 & 0.534 & & & & \\
\hline 4. Regular use & 0.428 & 0.649 & 0.662 & & & \\
\hline 5. Intrinsic motivation & 0.543 & 0.287 & 0.371 & 0.571 & & \\
\hline 6. Extrinsic motivation & 0.516 & 0.247 & 0.301 & 0.471 & 0.851 & \\
\hline 7. Organization identification & 0.182 & 0.208 & 0.186 & 0.265 & 0.219 & 0.236 \\
\hline
\end{tabular}

\subsection{Structural model}

To test the research hypotheses, the structural model of the research was analyzed by the PLS method. A bootstrapping procedure (with 500 samples) was used to evaluate the significance of the path coefficients (Chin,1998). In Table 5 and Figure 1, path coefficients, t-values and hypothesis test results are given. To evaluate PLS models, R-squrae is utilized because the objective of PLS is to maximize explained variance rather than fit (Chin, 1998; Daskin, Arasli \& Kasim, 2015). ( $R^{2}$ for intrinsic motivation: 0.34; $R^{2}$ for extrinsic motivation: $0.27 ; R^{2}$ for organization identification: $0.11)$. In that respect, the $R 2$ of the endogenous constructs revealed that the explanatory power of the model was within the acceptable limits (Chin, 1998) Additionally, The Cohen's Indicator ( $\mathrm{f} 2$ ), which shows how useful each construct is for the structural model evaluated, is given in table 5 . Values of $0.02,0.15$, and 0.35 are considered small, medium, and large, respectively.

In the first hypothesis of the research, the effect of cyberloafing on intrinsic motivation was tested. Accordingly, it was concluded that cyberloafing for social purposes had a positive effect on intrinsic motivation ( $\beta$ : $0.39, p<.001$ ). In addition, social loafing on regular use has been found to have a positive effect on intrinsic motivation ( $\beta: 0.33, p$ $<.001)$. On the other hand, it has been understood that cyberloafing factors regarding learning and irregular use do not have a statistically significant relationship on intrinsic motivation. As a result, it can be stated that hypothesis $\mathrm{H}_{1}$ is partially accepted.

In the second hypothesis of the research, the effect of cyberloafing on external motivation was tested. It is seen that cyberloafing for social purposes has a positive effect on external motivation as well ( $\beta$ : 0.41, $p<.001, f 2$ : 0.189 ). Similarly, it has been concluded that cyberloafing factor on regular use has a low level of influence on external motivation ( $\beta: 0.24, p<.05, f 2: 0.056)$. On the other hand, it has been observed that cyberloafing for learning and irregular use has no effect on external motivation. Accordingly, hypothesis $\mathrm{H}_{2}$ is also partially accepted.

Finally, the effect of cyberloafing on organizational identification was investigated in the study $\left(\mathrm{H}_{3}\right)$. Accordingly, it was concluded that cyberloafing for social purposes had a negative effect on organizational identification ( $\beta$ : 0.31, $p<.001, f 2: 0.036$ ). Similarly, it was concluded that the cyberloafing factor related to irregular use negatively affects organizational identification ( $\beta$ : -0.25 , $p<.05, f 2$ : 0.045). In addition, cyberloafing for learning purposes was found to have a positive effect on organizational identification ( $\beta$ : $0.29, p<.05, f 2: 0.058)$. As a result, it can be stated that hypothesis $\mathrm{H}_{3}$ is also partially accepted. 


\section{Figure 1 - Structural model}

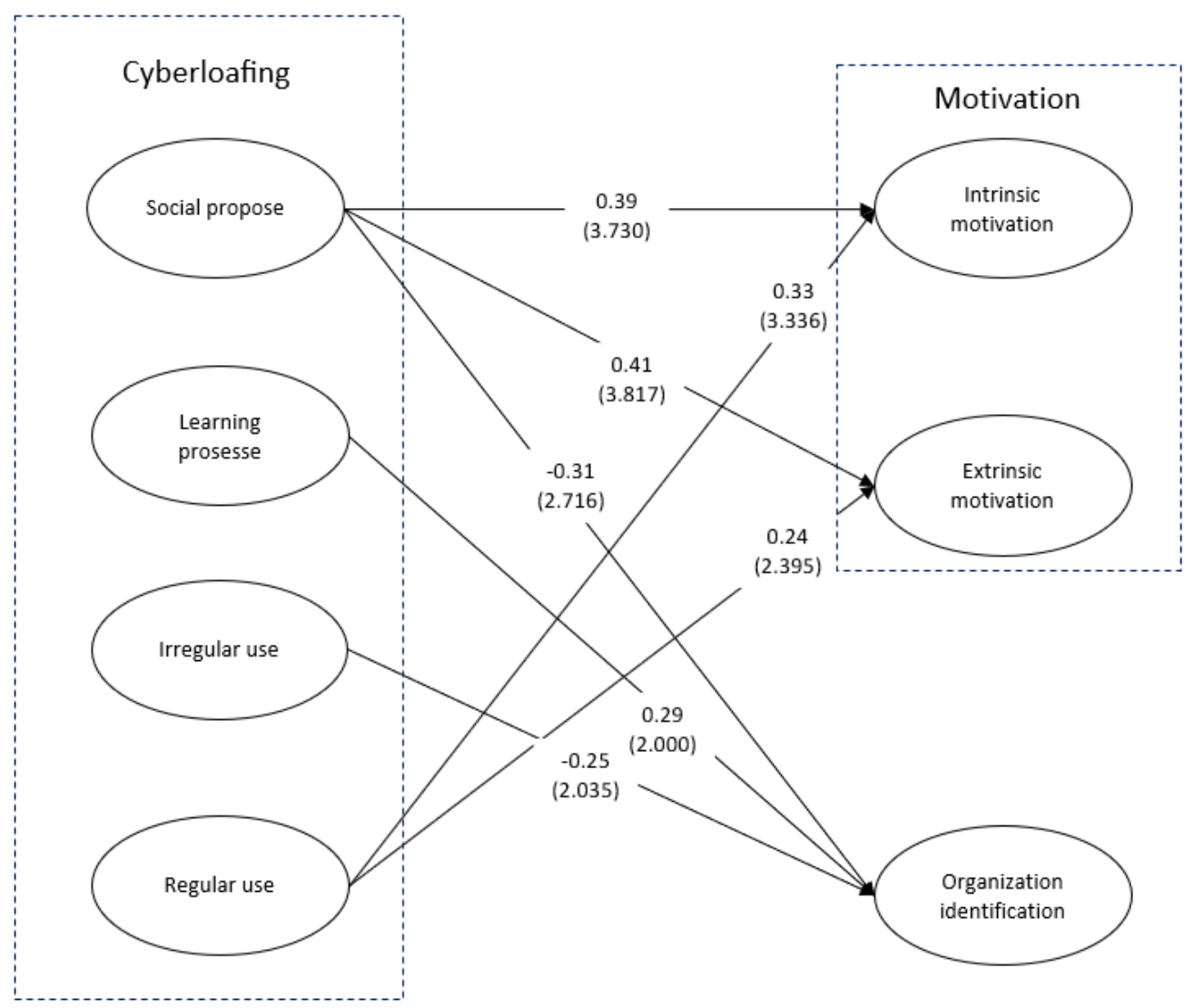

Table 5 - Structural model test results

\begin{tabular}{|c|c|c|c|c|}
\hline Hypothesized relationships & Path coefficient & T value & $f^{2}$ value & $\begin{array}{l}\text { Supported/ not } \\
\text { supported }\end{array}$ \\
\hline H1a. Social purpose -> Intrinsic motivation & 0.393 & $3.730 * *$ & 0.193 & Supported \\
\hline H1c. Irregular use -> Intrinsic motivation & 0.094 & 0.888 & 0.011 & Not supported \\
\hline H1d. Regular use -> Intrinsic motivation & 0.333 & $3.335^{* *}$ & 0.113 & Supported \\
\hline H2a. Social purpose -> Extrinsic motivation & 0.410 & $3.817^{* *}$ & 0.189 & Supported \\
\hline H2b. Learning purpose -> Extrinsic motivation & -0.096 & 0.858 & 0.009 & Not supported \\
\hline H2c. Irregular use -> Extrinsic motivation & 0.039 & 0.348 & 0.002 & Not supported \\
\hline H3b. Learning purpose -> Organization identification & 0.296 & $2.000^{*}$ & 0.058 & Supported \\
\hline H3c. Irregular use -> Organization identification & -0.251 & $2.034^{*}$ & 0.045 & Supported \\
\hline H3d. Regular use -> Organization identification & 0.075 & 0.484 & 0.017 & Not supported \\
\hline
\end{tabular}

Note: $\mathrm{R}^{2}: 0.175 * \mathrm{p}<.05 * * p<.001$ 


\section{Conclusions}

The increasing use of the internet day by day makes working life easier in many areas, but it also brings out new areas of sharing of social life that goes towards individualization. However, determining the effects of internet use on employee psychology and consequently employee performance will help determine the applications of businesses related to internet use. For this reason, today's businesses have developed many strategies and researches on the internet use of their employees. Revealing the effects of cyberloafing behaviors, which are the subject of this research, on employee motivation and feelings of identification with the organization, is important for businesses to determine the efficiency of the internet use and the attitudes of their staff. The main purpose in examining this relationship is to determine the effect of cyberloafing behavior on employee performance and to determine the efficiency-enhancing effect of control mechanisms on related variables.

In the evaluations made for the model of the research, motivation and cyberloafing dimensions were tested in the $\mathrm{H}_{1}$ hypothesis, and it was concluded that cyberloafing behaviors performed socially and regularly had a positive and significant effect on intrinsic motivation. According to this result, the cyberloafing behaviors of the employees regarding their socialization levels contribute to their internal motivation for the job. It is possible to evaluate this in two ways. Firstly, the employees fill the social gap in their work environments, which they cannot see as a socializing environment, with their cyberloafing behaviors and thus increase their motivation for their jobs through socializing activities. On the other hand, cyberloafing behaviors, which are other dimensions of cyberloafing such as learning and irregular use, do not affect the motivation of the employee in the business environment positively or negatively. This result partially supports the view in Carlson's and Zivnuska's studies that the use of social media (2016) affects employees positively, as well as resulting in stress relief by moving away from routine work to increase motivation as seen in the studies of Ugrin and Pearson (2013).

According to another hypothesis $\left(\mathrm{H}_{2}\right)$, when we examine the relationship between cyberloafing and external motivation, it is concluded that cyberloafing behavior that is done socially and irregularly has a positive and significant effect on external motivation. The important element that should be emphasized here is the tendency of two different motivation sources to be affected within the scope of this element, revealing that cyberloafing behavior for social purposes affects both internal and external motivation. Social loafing behavior, which is positively and significantly related to both dimensions of the motivation element with two different sub-dimensions, can undoubtedly be seen as an important motivation tool for the employee who is expected to be motivated in the work environment. This result supports the conclusion that the organizational motivation factors in the study conducted by Stanton (2002) are related to internet usage rates. According to the results of the research conducted by Ince and Gül (2011), we see a parallel result to the findings regarding the positive effect of cyberloafing behaviors on performance and motivation. According to these data, motivation factors are directly related to the tools to motivate individuals. Because, in the work environment, the tools of the enterprises to motivate the employees are external motivating tools. Although these vary depending on the motivational strategies of the business, these are often rewarding practices such as wages, days off, social opportunities, or promotion. However, the most important factor in maintaining organizational identification, feeling of belonging and loyalty to the organization is intrinsic motivation. Intrinsic motivation is related to the emotional and cognitive aspects of personal employees, such as the need to know, the desire to be sufficient, and the desire to develop. In addition, it has been concluded that cyberloafing behaviors that are exhibited for learning purposes are not effective on external motivation. Considering that the purpose of learning here is often related to the job being studied and acting with a learning motive, we can conclude that the cyberloafing behaviors of the employees to obtain information on a regular basis do not motivate them regarding their work areas.

However, when evaluated with organizational identification $\left(\mathrm{H}_{3}\right)$, another dimension of the research, the cyberloafing behavior used for social purposes affects organizational identification significantly and negatively. It is possible to explain this effect as the employees' preference towards socialization in a different environment than working environments and preference towards platforms in different areas instead of the insufficient level of socialization in the working environment. However, it is concluded that the cyberloafing behaviors shown in relation to the tasks to be performed affect the organizational identification factor positively and significantly, and that employees can regularly engage in certain cyberloafing behaviors during working hours that bring them closer to the organization as a degree of identification. This result does not support the results that organizational commitment and cyberloafing are negatively related in previous studies (Garrett \& Danziger, 2008; Niaei,2014). However, there are no conclusions that support the level of unrelatedness obtained in different studies in the same way (Candan \& Ince,2016).

The conclusion that the effects of cyberloafing behaviors, which are the variables of this research in general, on motivation and organizational identification are partially meaningful and effective, is important in terms of making sense of the research as a problem. Considering that today's work environments are becoming more and more integrated with many behaviors and activities in social life, the degree of separation of work activities and social activities appears to be a pending solution for businesses. Although the restriction or full integration strategies applied by many companies in this regard show the effect of the business vision on the employees, the data obtained provides important information about the efficiency 
strategies that the companies will implement. Businesses, who are very sensitive about organizational identification and commitment to organizations, have to manage the effect of cyberloafing behavior in performance indicators, which are shown as efficiency measures of many businesses, even though they implement highly flexible and libertarian policies with modern human resources and business strategies. Although the degree of use of cyberloafing behavior with different subdimensions is seen as a productivity-decreasing factor by some employees, it is accepted as a tool for some employees to be motivated by their jobs. As a result of the fact that the motivation levels of people who work completely isolated from their social life in the work environment can be negatively affected, it is an important decision in terms of attitude towards cyberloafing behaviors in terms of the business environment and the organizational culture to be created. A strong organizational culture and a high degree of socialization will be created, and the use of cyberloafing behaviors for businesses will only allow companies to pursue much more effective strategies in determining their level of efficiency, either regularly or irregularly, as a means of motivation. The fact that the research was carried out only in a certain region, that seasonal hotels were closed during the research process, and that the tourism enterprises in the region were small and not high in capacity are evaluated within the limitations of the research. The implementation of this study to tourism businesses in different regions and to businesses of different capacities may be useful in terms of different evaluations that may arise.

\section{References}

Anandarajan, M. \& Simmers, C. (Eds.) (2014.) A personal web usage in the workplace: a guide to effective human resources management. Hensey, Pa: Information Science Publishing.

Anandarajan, M., Devine, P. \& Simmers, C. A.(2004). A multidimensional scaling approach to personal web usage in the workplace. In M. Anandarajan \& C. Simmers (eds.), Personal Web Usage in the Workplace: A Guide to Effect Human Resource Management (pp. 6167). Hersey, PA: Idea Group.

Ashforth, B. E. \& Mael, F. (1989). Social identity theory and the organization. Academy Of Management Review, 14(1), 20-39.

Aslan, Z., Çoban, G., \& Çokal, Z. (2014). Turizm Öğrencilerinin Staj Deneyiminde Algıladıkları Motivasyonun Herzberg Kuramına Göre Değerlendirilmesi: Nevşehir Hacı Bektaş Veli Üniversitesi Turizm Fakültesi Örneği. Sosyal And Beşerî Bilimler Araştırmaları Dergisi, (33), 164-188.

Afthanorhan, W. M. A. (2014). Hierarchical component using reflectiveformative measurement model in Partial Least Square Structural Equation Modeling (PIs-Sem). International Journal of Mathematics and Statistics Invention (IJMSI), 2(2), 33-49.

Beugre, C. D., \& Daeryong, K. (2006). Cyberloafing: vice or virtue? in Mehdi Khosrow-Pour (Ed.), Emerging trends and challenges in information technology management (pp. 834-835). Hershey: IGI Global.

Blanchard, A. L., Henle, C. A. (2008). Correlates of different forms of cyberloafing: the role of norms and external locus of control. Computers in Human Behavior, 24(3), 1067-1084.

Block, W. (2001). Cyberslacking, business ethics and managerial economics. Journal Of Business Ethics, 33(3), 225-231.
Bratton, J., \& Gold, J. (2007). Human resource management: theory and practice, 4th Edition, Basingstoke: Palgrave.

Candan, H., \& İnce, M. (2016). Siber Kaytarma And Örgütsel Bağılıık Arasındaki İlişkinin İncelenmesine Yönelik Emniyet Çalışanları Üzerine Bir Araştırma. Ömer Halisdemir Üniversitesi iktisadi And Idari Bilimler Fakültesi Dergisi, 9(1), 229-235.

Carlson, J. R., Zivnuska, S., Harris, R. B., Harris, K. J., \& Carlson, D. S. (2016). Social media use in the workplace: a study of dual effects. Journal of Organizational and End User Computing, 28, 15-31. doi: 10.4018/JOEUC.2016010102

Cheney, G. (1983). The rhetoric of identification and the study of organizational communication. Quarterly Journal Of Speech, 69, 143158.

Chreim, S. (2002). Influencing organizational identification during major change: a communication-based perspective. Human Relations, 55(9), 1117-1137.

Çetinkaya, A. Ş. (2011). The impact of employee motivation on emotional commitment: research undertaken in a five-star hotel. Journal of Transnational Management, 16(3), 149-156.

Chin, W. W. (1998) The partial least squares approach for structural equation modeling. in Marcoulides, G.A. (Ed.). Modern methods for business research (pp. 295- 236). London: Lawrence Erlbaum Associates.

Daskin, M., Arasli, H., \& Kasim, A. (2015). The impact of management commitment to service quality, intrinsic motivation and nepotism on frontline employees' affective work outcomes. International Journal of $\begin{array}{llll}\text { Management } & \text { Practice, } & \text { 269-295. }\end{array}$ https://doi.org/10.1504/IJMP.2015.073492

Doorn, O.V.N. (2011). Cyberloafing: a multi-dimensional construct placed in a theoretical framework". Unpublished MBAThesis. Eindhoven University of Technology, Department Industrial Engineering and Innovation Sciences.

Edwards, M.R. (2005). Organizational identification: a: conceptual and operational review. International Journal Of Management Reviews, 7(4), 207-230.

Eivazi, K. (2011). Computer use monitoring and privacy at work. Computer Law and Security Review, 27(5), 516-523.

Fındıklı M., (2016). Sanal Kaytarma Ve İ̧ Performansı Ilişkisi: Sağlık Ve Tekstil Sektörü Çalışanlarının Karşılaştııııması. Sosyal Bilimler Enstitüsü Dergisi Cilt, 9, 33-62.

Foote, N. (1951). Identification as the basis for a theory of motivation. Amerikan Sociological Review, 16(1), 14-21.

Garrett, R. K., \& Danziger, J. N. (2008). Disaffection or expected outcomes: understanding personal internet use during work. Journal of Computermediated Communication, 13, 937-958.

Genç, E., \& Aydoğan, E. (2016). İ̧yerinde Sanal Tembellik Davranışı And Etkin Zaman Yönetimi İlişkisi: Bir Kamu Kurumunda Araştırma. Gazi Üniversitesi iktisadi And Idari Bilimler Fakültesi Dergisi, 18(2), 558-571.

Güney S., (2011). Örgütsel Davranış, 1. Basım, Ankara: Nobel Yayın Dağııım.

Gold, A. H., Malhotra, A., \& Segars, A. H. (2001). Knowledge management: an organizational capabilities perspective. Journal of Management Information Systems, 18(1), 185-214.

Hall, D. T., \& Schneider, B. (1972). Correlates of organizational identification as a function of career pattern and organizational type. Administrative Science Quarterly, 17(3), 340-350.

Harris, G. E., \& Cameron, J. E. (2005). Multiple dimensions of organizational identification and commitment as predictors of turnover intentions and psychological well-being. Canadian Journal of Behavioural Science 37(3), 159-169.

Harris, G., Cameron, J., \& Lang, J. (2011). Identification with community-based hiv agencies as a correlate of turnover intentions and general self-efficacy. Journal of Community and Applied Social Psychology, 21, 41-54. 
Henseler, J., Ringle, M. \& Sarstedt, M. (2015). A new criterion for assessing discriminant validity in variance-based structural equation modeling. Journal of the Academy of Marketing Science, 43 (1), 115-135 Hulland, J. (1999). Use of Partial Least Squares (PLS) in strategic management research: a review of four recent studies. Strategic Management Journal, 20(2), 195-204.

Ince M. \& Gül H., (2011). The Relation of cyber slacking behaviors with various organizational outputs: example of Karamanoğlu Mehmetbey University. European Journal of Scientific Research, 52(4), 507-527.

İşgüzar, S. \& Ayden, C. (2017). Siber Aylaklık Üzerine Değerlendirmeler: Toplu Bir Bakıs, 4th International Regional Development Conference (Irdc'2017), 21-23 September 2017, Tunceli/Turkey.

Jandaghi, G., Alvani, S. M., Matin, H. Z., \& Kozekanan, S. F. (2015). Cyberloafing management in organizations. Iranian Journal of Management Studies, 8(3), 335.

Jia, H., Jia, R., \& Karau, S. (2013). Cyberloafing and personality: the impact of the big five traits and workplace situational factors. Journal of Leadership Organizational Studies, 358-365.

Johns, G. (2006). The essential impact of context on organizational behaviour. Academy Of Management Review, 32(2), 386-408.

Johnson, P. R., \& Indvik, J. (2003). The organizational benefits of reducing cyberslacking in the workplace, Proceedings of the Academy of Organizational Culture, Communications and Conflict, 7(2), 53-60.

Kaplan, M. \& Öğüt, A. (2012). Algılanan örgütsel adalet ile sanal kaytarma arasındaki ilişkinin analizi: hastane çalışanları örneği. İşletme Fakültesi Dergisi, 13(1), 1-13.

Kutanis, R., Karakiraz, A., \& Aras, M. (2014). iş Stresi Sanal Kaytarma Üzerinde Etkili Midir?, Paper Presented At The 2. Örgütsel Davranış Kongresi, Kayseri.

Li M., \& Chung T., (2006). Internet function and internet addictive behaviour. Computers in Human Behavior, 22(6), 1067-1071.

Lim V. K. G. (2002). The it way of loafing on the job: cyberloafing, neutralizing and organizational justice. Journal of Organizational Behavior, 23(5), 675-694.

Lim Vivien K.G., Don J.Q., \& Chen, (2012). Cyberloafing at the workplace: gain or drain on work?, Behaviour and Information Technology, 31(4), 343-353.

Lim, V. K., \& Teo, T. S. (2005). Prevalence, perceived seriousness, justification and regulation of cyberloafing in singapore: an exploratory study. Information and Management, 42(8), 1081-1093.

Mael, F., \& Ashford B., (1989). Social identity theory and organization, The Academy of Management Review 14(1) 20-39.

Mael, F. \& Asforth, B.E. (1992). Alumni and their alma mater: a partial test of the reformulad model of organizational identifiaciton. Journal of Organizational Behavior, 13, 103-123.

Mahatanankoon, P., \& Igbaria, M. (2004). Impact of personal internet usage on employee's well-being. In M. Anandarajan \& C. A. Simmers (Eds.), A personal web usage in the workplace: a guide to effective human resources management, Hensey, Information Science Publishing.

Marcus, B., \& Schuler, H. (2004). Antecedents of counterproductive behavior at work: a general perspective. Journal of Applied Psychology, 89(4), 1-31.

Marlies, N., Tripepi, G., Dekker W., Zoccali C., Tanck M., \& Jager K. (2010). Sample size calculations: basic principles and common pitfalls. Nephrol Dial Transplant, 1388-1393, doi: 10.1093/ndt/gfp732

Mastrangelo, P. M., Everton, W. \& Jolton, J. A. (2006). Personal use of work computers: distraction versus destruction. Cyberpsychologyve Behavior, 9(6), 730-741.

Mignonac, K., Herrbach, O., \& Guerrero, S. (2006). The interactive effects of perceived external prestige and need for organizational identification on turnover intentions. Journal of Vocational Behavior, 69(3), 477-493.
Mills, J. E., Hu, B., Beldona, S., \& Clay, J. (2001). Cyberslacking! a wiredworkplace liability issue. The Cornell Hotel and Restaurant Administration Quarterly, 42(5), 34-47.

Morksness, L. (2014). Verbal measure, or graphic measure, or both? Psychometric study of organizational identification. Master's Thesis in Psychology Uit Norway's Arctic University.

Niaei, M., Peidaei, M. M., \& Nasiripour, A. A. (2014). The relation between staff cyberloafing and organizational commitment in organization of environmental protection. Kuwait Chapter of the Arabian Journal of Business and Management Review, 3(7), 59-71.

Örücü, E. \& Yıldız, H., (2014). İşyerinde Kişisel İnternet Ve Teknoloji Kullanımı: Sanal Kaytarma, Ege Akademik Bakıs, 4(1), 99-114.

Öztürk, Z, \& Dündar H. (2003). Örgütsel motivasyon and kamu çalışanlarını motive eden faktörler. C.Ü.libf Dergisi, 4(2), 57-67.

Pallant, J. (2013). SPSS survival manual: A step by step guide to data analysis using IBM SPSS. (4th ed.). Crows Nest, NSW: Allen \& Unwin.

Ramayah T. (2010). Personal web usage and work inefficiency. Business Strategy Series, 11(5), 295-301.

Reade, C. (2001). Antecedents of organizational identification in multinational corporations: fostering psychological attachment to the local subsidiary and the global organization. Journal of Human Resource Management, 12(8), 1269-1291.

Riketta, M. (2005). Organizational identification: a meta-analysis. Journal of Vocational Behavior, 66(2), 358-384.

Robinson, S. L., \& Bennett, R. J. (1995). A typology of deviant workplace behaviors: a multidimensional scaling study. Academy of Management Journal, 38(2), 555-572.

Rotondi, T (1976). Identification, personality needs, and managerial position. Human Relations, 29(6), 507-515.

Ruthankoon R., \& Olu O. S., (2003). Testing Herzberg's two-factor theory the Tai construction industry. Engineering, Construction and Architectual Management, 10(5), 333-341.

Samsun Provincial Culture and Tourism Directorate (2020). Samsun'da Konaklama Imkanları, Retrieved 18.07.2020 from https://samsun.ktb.gov.tr/TR-60511/samsun39da-konaklamaimkanlari.html

Scheuermann S., \& Langford, L. (1997). Cyberslacking! A liability issue for wired workplaces. Cornell Hotel and Restaurant Administration Quarterly 42(5), 34-47.

Schneider, B., Hall, D.T. \& Nygren, H. T. (1971). Self image and job characteristicsas correlates of changing organisational identification. Human Relations, 24(5), 397-416.

Serttaş, O., \& Şimşek, G. (2017). Konaklama İ̧̧letmelerinde Siber Aylaklık: Çalışanların Demografik Özellikleri Ille Siber Aylakııkları Üzerine Bir Araştırma. Uluslararası iktisadi And Idari Bilimler Dergisi, 3(1), 20-34.

Seymour, L., \& Nadasen, K. (2007). Web access for it staff: a developing world perspective on web abuse. The Electronic - Library, 25(5), 543557.

Stanton, J.M. (2002). Company profile of the frequent internet user. Communications of the ACM, 45(1), 55-59.

Syaebani, M. I., \& Sobri, R. R. (2011). Relationship between organizational justice perception and engagement in deviant workplace behavior, The South East Asian Journal Management, 5(1), 37-49.

Tolman, E.C. (1943). Identification and the post-war world. Psychological Review, 38(2), 141-148.

Ugrin, C. J., Pearson, M. J. \& Odom, M. D. (2007). Profiling cyber-slackers in the workplace: demographic, cultural, and workplace factors. Journal Of Internet Commerce, 6(3), 75 -89.

Ugrin, C., \& Pearson M., (2013). The effects of sanctions and stigmas on cyberloafing. Computers in Human Behavior, 29(3), 812-820.

Vitak, J., Crouse, J. \& Larose, R. (2011). Personal internet use at work: understanding cyberslacking, Computers In Human Behavior, 27, 17511759. 
Yıldırım, M., \& Arslan, Ö. E. (2015). İşgörenlerin iş motivasyonunun örgütsel bağlııklarına etkisi: Ankara'daki Beş Yıldızlı Otel İşletmelerinde Bir Araştırma. Turizm Akademik Dergisi, 2(1), 23-37.

Yıldız, B., \& Yıldız, H. (2015). İş yaşamındaki sanal kaytarma davranışlarının hukuki yönden incelenmesi. Bandırma libf Yonetim ve Ekonomi Araştırmaları Dergisi, 13(3), 1-17.

Yıldız, H., Yıldız, B., \& Ateş, H. (2014). Sanal kaytarma davranışlarının sergirilmesinde örgütsel adalet algısının rolü var mıdır? Bilgi Ekonomisi And Yönetimi Dergisi, 10(2), 55-66. 